\title{
Relationship of Leadership and Organizational Climate Indispensable Element to Facilitate Employee Engagement
}

\author{
Rajeesh Viswanathan, N. Sarath Lal, Veena Prasad, Jahira Parveen
}

\begin{abstract}
:
Purpose - Present study is a descriptive and analytical in nature aiming to bring out the relationship of leadership and organizational climate on employee engagement of the employees working in IT companies of South India.

Design/Methodology/Approach- This study adopts descriptive and analytical approach it, starts with clear variables which are derived from theory and based on these variables. The data for the study was collected through the structured questionnaire. The sample for the present study was collected from the IT companies working in South India. A total 785 questionnaires were returned by the respondents, this indicating a response rate of $59 \%$. The questionnaire uses five point Likert type response format is used for all the measures ranging from strongly agree to strongly disagree. SPSS 21 and Microsoft excel are the statistical packages and Independent correlation and regression are the tools used in the present study

Findings- A significant relationship was found between leadership and organizational climate with employee engagement of the employees working in IT companies of South India. It further shows that when there is a conducive working environment prevailing in the organization the employees feel a sense of conducive climate which makes them feel good about the organization and motivates them to work. Further, along with climate transformational leadership style facilitates in grooming the employees according to organizations vision. Hence, it's observed that these factors facilitate in enhancing employee engagement. Employees with skills and potentials are more preferring transformational leadership style. Employees with potentials always aspire to grow along with the organization. Hence, leadership style plays a vital role in engaging the employees.

Originality/value- This study provides insightful findings in understanding the role organizational competencies like leadership and organizational climate play in facilitating employee engagement. This study also shows the importance of the demographic variables with employee's engagement. In spite of the limitations of the research, the study contributed to the international human resources management by exploring the South Indian IT company's context. The theoretical framework proposes the relationship between employee engagement, organizational climate and leadership style. The study has found that organizational climate and transformational leadership is correlated with employee engagement and serves as the important indicator for engaging employees.
\end{abstract}

Revised Manuscript Received on July 05, 2019

Dr. Rajeesh Viswanathan, Asst Prof, Dept of International Business, School of Management, Pondicherry University, Pondicherry, India.

N. Sarath Lal, Dept of International Business, School of Management, Pondicherry University, Pondicherry, India.

Dr Veena Prasad, Prof, Shir Ram college of Commerce, Mumbai

Dr. Jahira Parveen, Faculty of Management, SRM Institute of Technology, Chennai, Tamizhnadu, India.
Index Terms: Employee Engagement, Organizational Climate and Leadership.

\section{INTRODUCTION}

Globally employee engagement had develop drastically and had earned the attention of HR professionals. In the modern business environment, the mangers demand for higher productivity by increasing efficiency when compared with previous year. With this higher pressure the organization are making a full and pure effort to increase their employees. Performance to increase the organizations among the competitions. Once it was easy to implement because there were employees who are satisfied with their organization and had work experience and stayed in the company for a longer period of time and contributed to the organization and thereby there was an increase in productivity. But the situation have been changed because satisfied employees are not enough to meet the demands and lead to high performance in the increasing business environment and competition.

In the increasing global competition, the organizations wants their employees to show initiative, to be responsible and to be with excitement and enthusiasm for their development. For achieving this employees had to go beyond satisfaction and commitment and work with full potential and capabilities and dedicate to their work which in other word is known as "Engagement".

The organizations have realized that in today's global environment, human resource management is the mainly concentrated term by which attracting, retaining and keeping them committed and mostly 'engaging' to reach the organizational goals. An engaged employee acts an ambassador for the company and they do not shift from one organization to the other organization and they are able to produce better performance and increase productivity. This can be achieved only when the employees think their organization as their own and respects the work given to them and contributes to performance and with all these they should have a personal growth along with the organization.

People think employee engagement had come into existence with the growth of industries like information technology but which is not true; it is a very old concept where the old leaders have built a commitment psychologically and led their men on their way to greatness. As indicated by statistics from the Conference Board, worldwide GDP developed at a rate of roughly $2 \%-3 \%$ in 2013 and is gauge to grow $3 \%$ in 2014 . However a checkout the globe highlights a fascinating movement in the offer of aggregate worldwide GDP. Substantial, full grown economies have been settling at lower levels of 
development, while the little rising economies have been developing at much high yearly rates. The result is that, on the whole, rising economies have overwhelmed full grown economies in 2014 and past. Rising economies keep on being an imposing nearness yet a great part of the forceful development we have found as of late is flattering. Development gauges are most grounded and higher than worldwide midpoints in China, India and sub - Sahara Africa. In any case, a portion of the exceptional development found in Asia and Latin America has hindered, bringing about expanded impression of monetary constriction with respect to the late history of extremely solid development. These movements have enormous ramifications from an ability point of view in the organizations working exclusively in one locale, furthermore for multinationals working over a few districts. An impeded pace inside developing markets displays new difficulties very natural to those in full grown markets. In the year 2010-11 the Indian IT sector rose after 18 months of stay nor growth. Then the IT started to grow and increased in revenue as the global market also started to grow and they were in a stabilized position. The IT started to grow at a rate of $20-24 \%$ in the first 6 months of the fiscal year when compared to the previous year. In 2014, there was a demand in global sourcing overall which grew by $9-10 \%$ from 2013 , which was twice the growth and India maintained its leadership position with 55\%. In 2015 the IT-BPM growth was a slow growth only with $0.4 \% \quad 1.2$ USD trillion. There was a decline of $-0.2 \%$ in IT and packages software had a growth of $0.2 \%$. With a share of $56 \%$ India continued to be the number one sourcing destination

Employee engagement is one of the main driving force and a biggest advantage for organization and there is a great certainty that employee engagement is connected with business performance Harter et al, (2002). As there are so many definitions and advantages given for employee engagement it is seen that there is disengagement is being developed among the employees Richman (2006) and so this study intends to check employee engagement with organizational climate and leadership style and the contribution of the variables to employee engagement. This study focuses on employee engagement in selected five IT companies from India.

\section{REVIEW OF LITERATURE}

\section{Organizational climate}

“Organizational climate is being called people's perception and mindset in regards to the organization "Wendell $\mathrm{L}$. French and Cecil H. Bell (2004). Individuals into the company have actually specific goals, and fulfillment regarding the individual objectives, based upon their perception, whether organizational climate suits based on their needs or not, Ritu Lethal (2004). Organized climate that is as a measure of individual perceptions or emotions about a small business. Organizational climate includes aspects that are certain are key as management or leadership styles, participate in choice generating, provision of challenging jobs to workers, reduction of monotony and frustration, supply of benefits, personnel policies, method of getting good working conditions and creation of suitable occupation ladder for academics. Nicholson and Miljus 1992. Academicians see their organizational climate through characterized factors such as Unchallenging jobs, shortage of workers where lecturers are required to perform responsibilities, that have been allowed to be achieved by other workers, absence of feedback about performance, not enough recognition for work done well through merit or announcements in meetings, insufficient product resources which can make it difficult for workers to undertake duties, poor communication where there's no two-way discussion between supervisors and subordinates and not sufficient staff development tasks which prevent personnel from being equipped with knowledge and ability that you can provide quality solution Fajana, 2002. Organizational climate represents the health of the organization's culture which is the most common administration issue faced by company in these current times in seek out creative flexible working climate that encourages work satisfaction and innovation that they require so. Being affected by fiscal constraints, downsizing, and needs which can be outsourcing to alter traits into the workforce that is into presence. Rekha Nair 2006 within their research noted the value that is increasing of climate on worker work satisfaction, creativity, retention and inspiration.

According to Wong and Wong (2002), a climate characterized by extreme competition or interaction that is poor is interpersonal stimulate stress during the workplace. Likewise, a small business that adopts a strict and alarming management design is generally more stressful to get leads to in comparison to one that has a far more versatile and movement that is supportive. A firm that is regarded as having a relaxed framework, supplying freedom in choice generating, accentuating rewards, promising challenge when it comes to goals and risk-taking, and nurturing heat, support, open-communication, and a sense of recognition, is less likely to want to be a provoking role conflict and role ambiguity among its sales workers to the financial services sector. Such a climate that is commendable is organizational in modification, tends to end up in reduced anxiety.

\section{Leadership Style}

Neha Verma, Aruna B. Bhat, S. Rangnekar and M.K. Barua (2015), considers leadership design plus the option making types of officials in the fabricating that is Indian, because of this research the specimen was drawn from Indian assembling associations' administrators from both available and individual divisions. The individuals have been paid down, center and amounts that are senior included into leadership and choice capabilities that can easily be making. Connection, relapse and ANOVA have been helpful to look for following the research issues. The research inferred that Indian fabricating administrators have actually demonstrated most noteworthy balanced and avoidant that is minimal their choice making designs. Transformational (TFM) leaders are observed objective, despite the fact that the transactional (TSL) leaders have actually emerged to be levelheaded and subordinates.

Bursts (1978) point down that leadership behavior may be arranged as either transactional or transformational. By rush (1978), transformational leadership will be the relationship between your frontrunner as well as the subordinate is dependent upon the feelings. 
While the style that is transactional of is dependent upon the equal and relationship that is deterministic a leader and their subordinates. The bottom line is it may be reported that transactional leaders work inside the demands linked to the ongoing company though transformational leaders exchange the business (Bass, 1985). In transformational leadership leaders can encourage subordinates by joining using them inwardly, which supply the possibility to share a dream. The partnership that is enthusiastic the subordinate doesn't end with motivation. A leader that is transformational this relationship with act as a guide or engineer showing to your an that is subordinate emphasis it (or in other words. solitary concept). The first option that is transformational the scholarly incitement of these subordinates. Around right here, the choice that is best that is transformational or coaches the subordinates in examining the existing situation, or considering old problems in brand-new means (Bass, 1985; Reese, 2005)

Transactional leadership is portrayed in a variety of means. Initially, a front-runner that is transactional rewards that are unanticipated age. g. Make use of pay or time down) to underlie the courses of action for unequivocal or concurrence that is sure objectives become arrived at have the fancied honors or conduct (Bass, 1981, 1985, 1997). 2nd, the first option that is transactional an administration by-special instance arrangement to perform an observing task that enables them to amass behavioral information to anticipate or keep consistently the subordinate from going astray from the significant amounts of goals (Bass, 1981, 1985, 1997). Third, transactional leaders are more often than not latent and just take action whenever a problem emerges (Judge and Piccolo, 2004).

\section{Employee engagement}

Tomlinson 2010 conducted a case that is practical from kia motors - the south korean maker that is automotive employees a lot more than 2500 individuals. The corporation deals in dealership work. The studies in regards to the elements being basic impact the Employee Engagement within an organization and also to realize the principles that are basic bettering the amount of worker engagement. And also comprehended that for growth of work engagement strategy, the unit is utilized by them called SOSTAC, which assists for staging case study. Pritchard 2008 identified that lots of inferences should be noted across both public and sector that is personal in British. By keeping founded reports in your mind, Monitoring staff options was indeed mandatory to all organizations especially during the time that is right of. The study was indeed performed centered on fundamental maxims of engagement as well as worker life period. Supervisors within the organizations arrived with numerous ways to manage modifications which are unavoidable workers that are keeping. David Guest 2014 done their research by utilizing previous reviews and suggested the significance of work and engagement that is organizational its important elements. The researcher tries to evaluate the core elements and illustrates distinction between your work as well as the organizational engagement as worker engagement is a core component within the administration activity. The researcher designed an investigation agenda for any work climate as well as for organizational engagement it generates usage of a thorough critique and an agenda to take care of the problems raised for any achievement of the goals. The findings revealed that, there exists a significant difference between work engagement with its ideas to improve the worker satisfaction and engagements that can be organizational its success requirements. The findings additionally figured, in to the engagement strategy it shows much more resilient base for work strategy rather than the other. Gupta and Kumar 2015 completed the extensive research in neuro-scientific worker engagement the part that is mediating of in Indian B-schools.

A survey have been completed among 320 participants have been employed in various B- schools in Asia. A Multiple regression model finished up working for canvassing the right part that is mediating of in to the relationship of justice and Employee Engagement. The end result establishes a correlation that is significant the distributive justice, procedural justice (PJ), straight justice (VJ) and Employee Engagement. The analysis additionally highlighted that the academics of B-schools had been affected and resulted by the amount that is good of this causes level that is advanced of. Alison Gill 2009 performed an instance research construction that is using Costain's task management Academy to explore the mind-set of worker engagement in to the climate that is changing. The researcher utilized Corlos' five stage type of behavioral modification for the construction for the study. The analysis primarily aims to dig to your characteristics of present modification that is organizational more eminent means of approaching it with the help of enduring behavioral and experience psychology by the workers. Both in public areas and personal sectors along with the "precision company Psychology" approach which enables you to whining the newest knowledge from mental technology with all the employee's years of expertise. The findings linked to the research give more value for just about any investing of that time period to alter the situation that is specific on the current modification with due consideration of previous administration process plus the employee's mindset that is behavioral. In addition identifies the worth of an approach that is precise both in purchase to provide effective interventions during the appropriate time and to determine progress.

\section{Research Gap}

Employee engagement is always an advantage for the organization in today's business environment which is competitively enough. But in India, the importance of employee engagement is different due to variety of reasons like diverse environment in each organization, leadership style followed by the managers. Considering these, the present study intends to concentrate on the climate and leadership style in the organization

\section{Need of the present study}

In the current global scenario organizations have been expanding in an exponential manner. NASSCOM annual report of 2012 states that the attrition rate is $27 \%$ in IT sector. In this process top management have been focussing more on strategies \& targets to expand and enhance their market share with minimal focus on 
the HR area. On the other hand HR has been into routine HR functions ignoring the factors like enhancing talent management and employee engagement. With this scenario, employees started moving from organizations for minimal gains since they were lacking engagement. Hence, it is felt that there is a need for the organisation to enhance employee engagement methods, in order to sustain steady growth and development.

\section{Scope of the Study}

The study intends to find employee engagement in the IT sector. India is one of the largest hub of IT industry and employee engagement is being measured from these companies. The respondents of this study are the employees from select five IT companies from south India.

\section{Statement of the problem}

To accomplish the organizational goals these IT companies rely on knowledge workers. Engaging a knowledge worker is a challenging task. For business performance to be achieved attracting and engaging the talent is needed for the organization and will be challenging enough. The ultimate objective of the organization to make employee engagement happen in the organization. Employee maximizing their value to the organization to increase engagement. But the definition of what it takes to make engagement happen is not based solely on competitive rewards; it is determined by the employee and is a moving target. The real challenge is faced not in hiring but in engaging them. Organizational Climate, Leadership Style play a vital role in engaging employees.

\section{Research Question}

The central research question of this study is to analyse how the organizational climate and leadership style influence employee engagement?

- What is the influence of organizational climate on employee engagement?

- What is the influence of leadership style on employee engagement?

\section{Objectives}

The major objective of the study is to find the relationship of organizational climate and leadership with the employee engagement.

\section{RESEARCH METHODOLOGY}

\section{Pilot Study}

A pilot study was conducted for a sample size of two hundred respondents and they were drawn from 5 IT sector of South India. The validity and the reliability of the scales were tested. The pilot study was done with no issues and some of the questions were eliminated after pre-testing.

\section{Population and Sample}

All units pertaining to a study is called a population and the sample is the subset of a population. According, to NASSCOM report, the top 5 companies were listed and from this companies the samples were chosen.

Table 1. Number of Employees from the Companies

\begin{tabular}{|l|l|l|}
\hline S.No. & Company & Employees \\
\hline 1 & Company 1 & 305431 \\
\hline 2 & Company 2 & 160,405 \\
\hline 3 & Company 3 & 154,297 \\
\hline
\end{tabular}

\begin{tabular}{|l|l|l|}
\hline 4 & Company 4 & 95,522 \\
\hline 5 & Company 5 & 95,300 \\
\hline TOTAL & 810955 \\
EMPLOYEES & & \\
\hline
\end{tabular}

\section{Sample Size Calculation}

The sample size for the population is calculated by the following formula.

$$
\text { Old SS }
$$

Sample Size =
(ss-1)
$1+--------$

pop

Where,

$\mathrm{SS}=$ - $\mathrm{Z}^{2}(\mathrm{p})^{*}(1-\mathrm{p})$

And the sample size is found to be 599.56 which is approximately 600 .

\section{MEASURIng InSTRUMENTS}

\section{Organizational climate scale}

Organizational climate scale was adapted from the literature Rao \&Abraham(1990)

The scale consists of seven dimensions of Role clarity, Respect, Communication, Reward system, Autonomy, Mutual Trust \& Confidence and Growth \& Development, where the scale was modified and adapted by the researcher in Indian context and the employees are asked to rate the scale from 1 to 5 with 5 had a score of strongly agree and 1 as strongly disagree.

\section{Leadership}

Leadership Scale was measured using the literature (Oztop,2008).The leadership scale has two dimensions such as Transactional leadership and Transformational leadership and the employees are asked to rate the leadership scale from 1 to 5 , where 5 has a score of " Strongly agree" and 1 as "Strongly Disagree".

\section{Employee Engagement}

Employee engagement scale was adopted from Wilmar B. Schaufeli and Arnold B. Bakker (2006). The scale has three dimensions one is Vigor the second is Dedication and third dimension is Absorption with five point scale where 1 is Strongly Disagree and 5 is Strongly Agree.

\section{Normality}

Normality is used to test whether the data distributed is normal. For the test to be normal it has to get skewness and kurtosis, where the values should range from +2 to -2 and the values are achieved in the study and so the data distribution is normal.

\begin{tabular}{|l|l|l|}
\hline Study variables & Skewness & Kurtosis \\
\hline Organizational Climate & -1.204 & 1.260 \\
\hline Leadership Style & -.356 & 1.204 \\
\hline Employee Engagement & 1.603 & 1.564 \\
\hline
\end{tabular}

\section{Reliability}

Cronbach Alpha was done too check the reliability of the data and it is found to be similar with the literature.

The scales for measuring the three organizational climate,

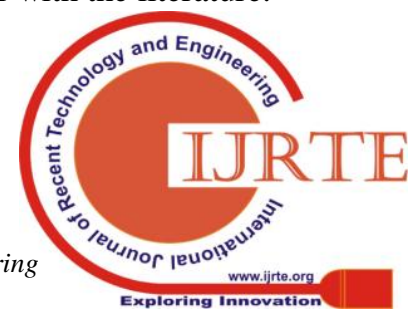


leadership, Employee and Employee Engagement were drawn from the study. Cronbach's Alpha co efficient for all the variables are greater than 0.7 and so we conclude the data is reliable.

\begin{tabular}{|l|l|}
\hline Study variables & Cronbachs Alpha \\
\hline $\begin{array}{l}\text { Organizational } \\
\text { Climate }\end{array}$ & 0.970 \\
\hline Leadership Style & 0.961 \\
\hline $\begin{array}{l}\text { Employee } \\
\text { Engagement }\end{array}$ & 0.975 \\
\hline
\end{tabular}

\section{Tools and software used}

The data collected is analysed with the statistical tools using SPSS20, Correlation and Regression is used to find the relationship between the variables

Data analysis

The objective of the study is to project the relationship of companies considered with respect to Employee Engagement.

The present study has 785 samples covering 5 companies namely Company $1\left(\mathrm{n}_{1}=153,19.49 \%\right)$, Company $2\left(\mathrm{n}_{2}=188\right.$, $23.95 \%)$, Company $3\left(\mathrm{n}_{3}=122,15.54 \%\right)$, Company $4\left(\mathrm{n}_{4}=\right.$ $165,21.02 \%)$ and Company5 $\left(\mathrm{n}_{5}=157,20.0\right)$. To observe the relation between the variables considered and to validate whether these variables are significant enough to explain about the employee engagement in each company, the so called statistical tools, Correlation and Regression analysis are considered.

\section{Correlation}

Correlation is being done to find the relationship between the study variable and the hypotheses are as follows

H1: There is a significant relationship between organizational climate and employee engagement.

$\mathrm{H} 2$ : There is a significant relationship between leadership style and employee engagement.

H3: There is a significant relationship between organizational climate and leadership style.

\begin{tabular}{|l|c|c|}
\hline Variables & $\begin{array}{c}\text { Pearson Co } \\
\text { efficient }\end{array}$ & Significance \\
\hline $\begin{array}{l}\text { Organizational } \\
\text { Climate ---> } \\
\text { Leadership Style }\end{array}$ & 0.884 & 0.000 \\
\hline $\begin{array}{l}\text { Organizational } \\
\text { Climate ---> } \\
\text { Employee } \\
\text { Engagement }\end{array}$ & 0.913 & 0.000 \\
\hline $\begin{array}{l}\text { Leadership Style } \\
\text {---> Employee } \\
\text { Engagement }\end{array}$ & 0.857 & 0.000 \\
\hline
\end{tabular}

On performing the correlation analysis it is evident that all the variables are highly and positively correlated with each other and are found to be significant at 0.05 level.

With respect to Employee Engagement, the variable Organisational Climate has the highest amount of Correlation (i.e.,) 0.913. The leadership is also have good extent of relation with Employee Engagement. This reflects that all these four variables tend to have good amount of contribution in explaining the variability with respect to Employee Engagement.

However, there is need to validate the contribution of each and every variable towards Employee Engagement.

\section{Multiple Regression Model}

After checking out the positive and strong relationship of organizational climate and leadership on employee engagement a multiple regression analysis has been done to check the impact of organizational climate and leadership on employee engagement.

Employee engagement predicated by Organizational climate and Leadership

\begin{tabular}{|l|l|}
\hline H4 & $\begin{array}{l}\text { There is a significant relationship between } \\
\text { organizational climate and employee engagement. }\end{array}$ \\
\hline H5 & $\begin{array}{l}\text { There is a significant relationship between } \\
\text { leadership and employee engagement. }\end{array}$ \\
\hline
\end{tabular}

\section{Model summary}

\begin{tabular}{|l|l|l|l|l|}
\hline \multicolumn{5}{|c|}{ Model Summary } \\
\hline Model & $\mathrm{R}$ & $\begin{array}{l}\mathrm{R} \\
\text { Square }\end{array}$ & $\begin{array}{l}\text { Adjusted } \\
\text { Square }\end{array}$ & $\begin{array}{r}\text { Std. Error of the } \\
\text { Estimate }\end{array}$ \\
\hline 1 & $.784^{\mathrm{a}}$ & .637 & .619 & .3151 \\
\hline a. Predictors: (Constant), Organizational climate, Leadership \\
\hline
\end{tabular}

\section{Interpretations:}

$\mathrm{R}$ is the correlation, its value is 0.784 and $\mathrm{R}$ square is the degree of determination, its value is 0.619 . The degree of determination show the extent to which organizational climate and leadership influence employee engagement. Here the employee engagement is determined to an extent of $61 \%$ by organizational climate and leadership.

\begin{tabular}{|c|c|c|c|c|c|c|}
\hline \multicolumn{7}{|c|}{ Anova Table: } \\
\hline \multicolumn{7}{|c|}{ ANOVA $^{a}$} \\
\hline \multicolumn{2}{|c|}{ Model } & Sum & offdf & Mean & $F$ & Sig. \\
\hline \multirow{3}{*}{1} & Regression & $\begin{array}{l}\text { Squares } \\
209.069\end{array}$ & 6 & $\begin{array}{l}\text { Square } \\
34.437\end{array}$ & 177.7919 & $.000^{\mathrm{b}}$ \\
\hline & Residual & 103.210 & 516 & 201 & & \\
\hline & Total & 312.279 & 522 & & & \\
\hline \multicolumn{7}{|c|}{ a. Dependent Variable: Employee engagement } \\
\hline & . $\mathrm{Pr}$ & Cons & ea & & nizatic & mate \\
\hline
\end{tabular}

ANOVA table shows that the significant value is less than 0.01 , which means the dependent variable that is employee engagement is significantly predicted by the independent variables namely organizational climate and leadership at $99 \%$ confidence level. 


\begin{tabular}{|c|c|c|c|c|c|c|}
\hline \multicolumn{7}{|c|}{ Coefficients $^{2}$} \\
\hline \multirow{2}{*}{\multicolumn{2}{|c|}{ Mode! }} & \multicolumn{2}{|c|}{ Unstandardized Coefficients } & \multirow{2}{*}{$\begin{array}{l}\begin{array}{l}\text { Standardized } \\
\text { Coefficents }\end{array} \\
\text { Beta }\end{array}$} & \multirow[t]{2}{*}{$\mathrm{t}$} & \multirow[t]{2}{*}{ Sig. } \\
\hline & & $\bar{B}$ & Std. Error & & & \\
\hline \multirow{3}{*}{1} & (Constant) & 319 & .149 & & .2 .141 & .024 \\
\hline & Organizational climate & .117 & .047 & .072 & 2.489 & .039 \\
\hline & Leadership & .674 & .049 & 4.15 & 13.755 & .000 \\
\hline
\end{tabular}

Work performance $=-0.325+0.117$ (organizational climate)

$$
+0.674 \text { (leadership) }
$$

Among the above two factors leadership have a significant and highest impact on the employee engagement. Organizational climate is significantly contributing to the employee engagement. Hypothesis [H4] is accepted and shows that is a significant relationship between organizational climate and employee engagement. Hypothesis [H5] is accepted and shows that there is a significant relationship between leadership and employee engagement.

\section{DiscuSSION AND CONCluSION}

The study suggest the companies to concentrate on all the variables equally in the organization as the analysis shows a good amount of relationship between the variables used in the study and all the variables plays a major role in contributing for employee engagement. Conducive Organizational Climate is imperative for engaging the employees. In the absence of conducive climate what so ever the motivational strategies are applied, it won't facilitate in retaining the employees. Any employee joins an organization keeping in mind a conducive working environment. Elton Mayo's study, “The First Inquiry" done at Mule spinning mills discusses on the importance of conducive organizational climate to retain the employees.

Employees with skills and potentials looks for a transformational leadership style. They don't prefer to work in a scenario where it's transactional in nature. Employees with potentials always aspire to grow along with the organization. Hence, leadership style plays a vital role in engaging the employees. On the other hand if the leadership style is transactional in nature employees will be having the feeling of belongingness towards the organization.

The theoretical framework proposes the relationship between employee engagement, organizational climate and leadership style. The two variables are highly significant with employee engagement and are good in engaging employees. The study has found that organizational climate is correlated with employee engagement and serves as the main variable in engaging employees. With organizational climate and leadership and employee engagement as variables the study has helped in developing a holistic model. This helps the other companies an easy approach to engage their employees by developing organizational strategies.

\section{Limitations}

The cross sectional design may hamper the applicability of causal conclusions drawn from the findings. The study used the self-rater to measure all the constructs. This study pertains to Chennai and Bangalore only and it may differ in other parts of the World. Five companies has been taken and some more companies can also be included.

Future Research
Future researcher can include more variables and can also use more tools and the data can be collected through different methods and the samples can also be increased. The data can be collected from different levels of employees like top management, middle management and can also be increased with organizational engagement, team engagement and job engagement.

\section{REFERENCES}

1. Anand Kumar Jaiswal, Shruti Gupta, (2015). "The influence of marketing on consumption behavior at the bottom of the pyramid", Journal of Consumer Marketing, Vol. 32 Issue: 2, pp.113-124, https://doi.org/10.1108/JCM-05-2014-0996

2. Bass, B. M. (1985). Leadership and performance beyond expectation. New York: Free Press.

3. Bass, B. M. (1990). From transactional to transformational leadership: Learning to share the vision. Organizational Dynamics, (Winter): 19-31.

4. Bass, B.M. and Riggio, R.E. (2006). Transformational Leadership (Second Edition), Routledge.

5. Fajana, S. (2002) Human Resource Management: An Introduction. Labofin and Company, Lagos.

6. Harter, J.K., Schmidt, F.L., \& Keyes, C.L. (2002). Well-Being in the Workplace and its Relationship to Business Outcomes., Open Journal of Social Sciences, Vol.5 No.6, June 15, 2017.

7. Joseph P. H. Fan and T. J. Wong, (2002), Corporate ownership structure and the informativeness of accounting earnings in East Asia, Journal of Accounting and Economics, 33, (3), 401-425.

8. Judge, T. \& Piccolo, R. (2004).Transformational and Transactional Leadership: A Meta-Analytic Test of Their Relative Validity, Journal of Applied Psychology, 5, 755-768.

9. Neha Verma, Aruna B. Bhat, S. Rangnekar, M. K. Barua, (2015) "Association between leadership style and decision making style in Indian organisations", Journal of Management Development, Vol. $34 \quad$ Issue: pp.246-269, https://doi.org/10.1108/JMD-03-2012-0038.

10. Nicholson, E.A and Miljus, R.C (1992), "Job Satisfaction and Turnover among Liberal Arts College Professors. Personnel Journal .51: 840-845.

11. Pecarich, Frank, (1983). - New Thoughts in Public Sector OD.\|In Wendell L. French. Cecil H. Bell. Jr., and Robert A. Zawacki, eds., Organization Development: Theory, Practice and Research. Plano, TX: Business Publications Inc.

12. Pritchard, A. (2008).,Ways of Learning: Learning Theories and Learning Styles in the Classroom, A David Fulton book, Taylor \& Francis

13. Rees, W. and Aldrich, R. J. (2005), Contending cultures of counterterrorism: transatlantic divergence or convergence? International Affairs, 81: 905-923. doi:10.1111/j.1468-2346.2005.00494.x.

14. Richman, A. (2006), "Everyone wants an engaged workforce how can you create it?", Workspan, Vol. 49, pp. 36-9. 